Jurnal Info Kesehatan

Vol 16, No.1, Juni 2018, pp. 96-105

P-ISSN 0216-504X, E-ISSN 2620-536X

Journal DOI: https://doi.org/10.31965/infokes

Website: http://jurnal.poltekeskupang.ac.id/index.php/infokes

R E S E A R C H

Open Access

\title{
Peningkatan Polymorphonuclear (PMN) Dalam Cairan Nasal Lavage Operator Penggilingan Padi Yang Terpajan Endotoksin Lipopolisakarida (LPS)
}

\author{
William Wilfridus Lamawuran \\ plamawuran@gmail.com
}

Jurusan Kesehatan Lingkungan, Poltekkes Kemenkes Kupang

\begin{abstract}
Abstrak
Latar Belakang: Paparan endotoksin lipopolisakarida (LPS) pada debu padi menyebabkan peradangan pada saluran pernapasan yang ditandai dengan peningkatan Neutrofil atau Polymorphonuclear (PMN) pada cairan nasal lavage operator penggilingan padi. Tujuan: Tujuan dari penelitian ini adalah untuk menganalisis pengaruh endotoksin LPS terhadap peningkatan kadar Polymorphonuclear (PMN) operator penggilingan padi. Metode: rancangan penelitian ini adalah longitudinal studi. Pengambilan sampel debu dilakukan selama 8 jam sedangkan sampel nasal lavage dilakukan sebelum dan setelah bekerja (cross shift). Kadar PMN dan LPS Endotoksin dianalisis menggunakan metode ELISA kemudian Endotoksin LPS dianalisis menggunakan LAL. Hasil: Rerata kadar endotoksin LPS dalam debu padi adalah 56,36 $\pm 5.83 \mathrm{EU} / \mathrm{m} 3$. Terjadi peningkatan PMN setelah kerja (Pired samplet test: $p=0.000$ ) pada semua operator penggilingan padi. Kadar endotoksin LPS berkorelasi dengan peningkatan PMN pada cairan nasal lavage operator penggilingan padi (uji regresi linear berganda: $p=0.000)$. Kesimpulan: Endotoksin LPS merupakan faktor yang mempengaruhi peningkatan kadar PMN dalam cairan nasal lavage yang mengindikasikan terjadinya inflamasi pada operator penggilingan padi. Disarankan: Menggunakan mesin penggilingan padi yang dilengkapi dengan pengumpul debu. Perlu pemeriksaan kesehatan secara berkala dan bagi pekerja yang mengalami gangguan pernapasan agar diberikan pengobatan dan waktu untuk istirahat dari pekerjaan nya. Pekerja disarankan untuk selalu menggunakan masker saat bekerja.
\end{abstract}

Kata kunci: Polymorphonuclear, Endotoksin, Penggilingan Padi 
Lamawuran, W. (2018). Peningkatan Polymorphonuclear (PMN) Dalam Cairan Nasal Lavage Operator Penggilingan Padi Yang Terpajan Endotoksin Lipopolisakarida (LPS). JURNAL INFO KESEHATAN, 16(1), 96-105. https://doi.org/10.31965/infokes.Vol16.Iss1.175

\title{
Increased Polymorphonuclear (PMN) in Nasal Lavage Liquid Rice Milling Operators Exposed to Lipotoxaccharide Endotoxin (LPS)
}

\begin{abstract}
Background: Exposure to lipopolysaccharide endotoxin (LPS) in rice dust causes respiratory inflammation which is characterized by an increase in Neutrophils or Polymorphonuclear (PMN) in the nasal lavage fluid of rice milling operators. Objective: The purpose of this study was to analyze the effect of endotoxin LPS on the rice mill operators' PM in the rice level operators. Methods: the design of this study was a longitudinal study. Dust sampling was carried out for 8 hours while nasal lavage samples were carried out before and after work (cross shift). Endotoxin PMN and LPS were analyzed using the ELISA method and LPS Endotoxin was analyzed using LAL. Results: The mean level of LPS endotoxin in rice dust was $56.36 \pm 5.83 \mathrm{EU} / \mathrm{m} 3$. An increase in post-employment PMN (Pired sample t-test: $\mathrm{p}=0.000$ ) in all rice milling operators. LPS endotoxin levels correlated with increased PMN in nasal lavage fluid in rice milling operators (multiple linear regression test: $\mathrm{p}=0.000)$. Conclusion: LPS endotoxin is a factor that influences the increase of PMN levels in nasal lavage fluid which indicates the occurrence of inflammation in rice mill operators. Suggestion: Use a rice milling machine equipped with a dust collector. Health checks are given to the rest of their work. Workers are advised to always use masks while working.
\end{abstract}

Keywords: Polymorphonuclear, Endotoxin, Rice mills

* Correspondence: plamawuran@gmail.com

Present Address: Jurusan Kesehatan Lingkungan,

Poltekkes Kemenkes Kupang, Kupang City, Indonesia.

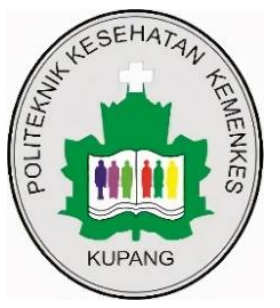

CThe Author(s) 2018. This article is distributed under the terms of the Creative Commons Attribution $4.0 \quad$ International License

(http://creativecommons.org/licenses/by/4.0/), which permits unrestricted use, distribution, and reproduction in any medium, provided you give appropriate credit to the original author(s) and the source, provide a link to the Creative Commons license, and indicate if changes were made. The Creative Commons Public Domain Dedication waiver (http://creativecommons.org/publicdomain/zero/1.0/) applies to the data made available in this article, unless otherwise stated. 


\section{PENDAHULUAN}

Gangguan pernapasan merupakan salah satu masalah yang sering dialami oleh pekerja disektor pertanian akibat terpapar debu. Organisasi Perburuhan Internasional (ILO) melaporkan bahwa sekitar 40.000 kasus baru pneumoconiosis (penyakit pernapasan akibat debu) terjadi di seluruh dunia setiap tahun (Antarudin, 2003).

Industri penggilingan padi menghasilkan debu yang cukup banyak. Terpapar debu padi yang mengandung Endotoksin Lipopolisakarida (LPS) dapat menyebabkan peradangan atau inflamasi saluran pernapasan (Poole, 2012). Inflamasi lokal terjadi 4 sampai 6 jam setelah paparan. Respon inflamasi terhadap LPS dalam bentuk fagositosis oleh makrofag yang memproduksi sitokin proinflamasi yakni Interleukin-1, Interleukin-6 dan Tumor Necrosis Factor Alpha (TNF- $\alpha$ ). Selanjutnya, Induksi TNF- $\alpha$ juga merangsang neutrofil untuk bermigrasi ke jaringan yang meradang dan melakukan fagositosis terhadap endotoksin LPS (O'Gradi et al, 2001; Hermawan, 2006:. Schwartz et al, 1992).

Peradangan menyebabkan produksi lendir yang berlebihan dan obstruksi pernafasan akut yang dapat dipulihkan (reversibel), kecuali paparan jangka panjang atau terus-menerus, dapat menyebabkan gangguan pernapasan kronis dan tidak dapat diubah seperti bronkitis kronis dan fibrosis paru yang menyebabkan penurunan fungsi paru ( Kennedy et al, 1994;. Djojodibroto 2014).

Paparan LPS endotoksin pada debu padi menyebabkan peradangan pada pekerja yang ditandai dengan pelepasan mediator peradangan yakni makrofag, PMN/neutrofil, dan sel-sel epitel saluran napas (Becker et al., 1999). Selain itu inflamasi juga mengundang respons dari sitokin proinflamasi seperti Interleukin-1 (IL-1), interleukin-6 (IL-6) dan TNF- $\alpha$ dalam serum darah pekerja penggilingan padi (Antarudin 2003; Sirait, 2010; Gezondheidsraad, 2011). Penelitian lain yang dilakukan pada hewan percobaan dengan menggunakan ekstrak debu jagung juga menunjukkan adanya respon inflamasi yang ditunjukkan oleh kenaikan total PMN/neutrofil $(p=0,001)$ dan tingkat TNF- $\alpha$ $(p=0,04)$ dalam cairan Bronchoalveolar Lavage (BAL) (Clapp et al., 1994).

Berbagai studi telah dilakukan untuk menganalisis inflamasi yang disebabkan oleh endotoksin LPS melalui pemeriksaan terhadap biomarker inflamasi pada serum darah atau Bronchoalveolar Lavage (BAL) sedangkan penelitian dengan menganalisis penanda peradangan dalam cairan nasal lavage (bilasan hidung) masih sangat 
Lamawuran, W. (2018). Peningkatan Polymorphonuclear (PMN) Dalam Cairan Nasal Lavage Operator Penggilingan Padi Yang Terpajan Endotoksin Lipopolisakarida (LPS). JURNAL INFO KESEHATAN, 16(1), 96-

105. https://doi.org/10.31965/infokes.Vol16.Iss1.175

terbatas. Oleh karena itu tujua dari penelitian ini adalah untuk menganalisis biological marker peradangan lokal dan akut yakni PMN dalam cairan nasal lavage operator penggilingan padi yang terpajan endotoksin LPS.

\section{METODE PENELITIAN}

Desain penelitian ini adalah studi longitudinal di mana pengambilan sampel dan pemeriksaan dilakukan sebelum dan setelah kerja (cross shift) pada 11 orang operator penggilingan padi dan dilakukan pada hari pertama kerja setelah libur dua hari. Pengukuran konsentrasi debu menggunakan Personal Dust Sampler (PDS) selama 8 jam kerja kemudian dianalisis dengan metode gavimetri. Pengukuran kadar endotoksin LPS pada debu personal dilakukan dengan menggunakan Limulus Amoebocyte Lysate (LAL) -Test.

Prosedur pengambilan sampel Nasal Lavage (NL) mengacu pada penelitian dari Keman et al (1998) sebagai berikut: Memberikan petunjuk secara saksama kepada responden mengenai tujuan dan prosedur pengambilan sampel Nasal Lavage sampai responden memahami dan menyatakan bersedia. Dalam posisi duduk, responden diarahkan untuk menegakkan lehernya ke atas hingga $45^{\circ}$, membuka mulut selebarlebarnya untuk meninggikan langit-langit agar menutup nasopharing dan menahan napas selama pengambilan sampel dilakukan. Sterile Phosphate Buffered Saline Solution $\mathrm{NaCl}$ sebanyak $10 \mathrm{ml}$ dimasukan ke dalam pipet steril kemudian dimasukan ke dalam lubang hidung responden kiri dan kanan masing-masing $5 \mathrm{ml}$. setelah 10 detik responden menundukan kepala untuk mengeluarkan cairan ke tabung centrifuge yang berukuran $15 \mathrm{ml}$ yang telah dipasang kasa steril untuk menyaring lender. Jika waktu sebelum pemeriksaan di laboratorium lebih dari 4 jam maka sampel disimpan di wadah yang terdapat es. Kemudian sampel di centrifuge pada $600 \mathrm{~g}$ selama 10 menit. Supernatan yang dibagi menajadi 8 aliqueos $(500 \mu \mathrm{L})$ disimpan pada suhu $70^{\circ} \mathrm{C}$ untuk selanjutnya dianalisis.

Sel PMN dianalisis dalam media cairan nasal lavage atau bilasan hidung. Langkah pemeriksaan merujuk pada prosedur yang pernah dilakukan oleh Wijaya et al (2012) sebagai berikut:

1. Cairan nasal lavage dipisahkan dari kontaminasi saliva dengan menggunakan disposable forceps.

2. Dicampur dengan larutan dithiothreitol 0,1 \% dengan perbandingan 1:1. 
3. Larutan di-vortex selama 15 menit dan disentrifugasi dengan 2000 rpm selama 10 menit.

4. Supernatant dibuang, sisa cell pellet dicampurkan lagi dengan media RPMI dengan perbandingan 4:1.

5. Selanjutnya disentrifugasi dengan 1500 rpm selama 10 menit dan supernatant dan sisa cell pellet yang ada dicampur dengan larutan PBS $200 \mu 1$.

6. Dibuat sediaan di atas object glass yang bersih dan diwarnai dengan Giemsa.

7. Slide diperiksa hitung jenis sel nya menggunakan mikroskop binokuler.
8. Dihitung jumlah sel Polymorphonucleardalam 10 lapangan pandang.

\section{HASIL DAN PEMBAHASAN}

a. Hasil

1) Hasil Pengukuran Kadar Debu Personal

Kadar debu personal diambil menggunakan personal dust sampler (PDS) dengan satuan $\mathrm{mg} / \mathrm{m}^{3}$. Distribusi kadar debu personal pada responden dapat dilihat pada gambar di bawah ini:

Tabel 1. Distribusi Kadar Debu Personal Operator Penggilingan Padi di Desa Palur, Kecamatan Kebonsari, Kabupaten Madiun Tahun 2015

\begin{tabular}{ccc}
\hline Kadar Debu $\left(\mathbf{m g} / \mathbf{m}^{3}\right)$ & Jumlah & Presentase \\
\hline$\leqslant \mathrm{NAB}\left(3 \mathrm{mg} / \mathrm{m}^{3}\right)$ & 8 & 72.73 \\
\hline NAB $\left(3 \mathrm{mg} / \mathrm{m}^{3}\right)$ & 3 & 27.27 \\
\hline Minimum $/ \mathrm{maksimum}$ & \multicolumn{2}{c}{$1.25 / 3.19 \mathrm{mg} / \mathrm{m}^{3}$} \\
\hline Rerata $\pm \mathrm{SD}$ & $2.199 \pm 0.723 \mathrm{mg} / \mathrm{m}^{3}$ \\
\hline
\end{tabular}

Tabel 1 menunjukan sebagian besar (72.73\%) kadar debu dibawah nilai ambang batas dan hanya $27.27 \%$ yang melebihi NAB yang ditetapkan olehy kementerian tenaga kerja RI No. 3 tahun 2011 tentang NAB pajanan fisik dan kimia ditempat kerja. Nilai kadar debu personal terendah adalah 1,25 $\mathrm{mg} / \mathrm{m}^{3}$ dan kadar debu personal tertinggi adalah $3,19 \mathrm{mg} / \mathrm{m}^{3}$. Rerata \pm SD kadar debu personal adalah $2.199 \pm 0.723 \mathrm{mg} / \mathrm{m}^{3}$. Variasi kadar debu personal dari setiap responden ini dipengaruhi oleh keberadaan masing-masing responden pada proses pekerjaan dimana ada responden yang bekerja pada penggilingan padi dengan konsentrasi debu yang lebih 
Lamawuran, W. (2018). Peningkatan Polymorphonuclear (PMN) Dalam Cairan Nasal Lavage Operator Penggilingan Padi Yang Terpajan Endotoksin Lipopolisakarida (LPS). JURNAL INFO KESEHATAN, 16(1), 96-

105. https://doi.org/10.31965/infokes.Vol16.Iss1.175

| 101

tinggi dibandingkan dengan pekerja yang bertugas pada proses pembersihan beras dan pengemasan.

2) Hasil Pengukuran Kadar Endotoksin Lipopolisakarida Dalam Debu Personal
Kadar endotkoksin lipopolisakarida dalam debu personal dianalisa menggunakan teknik sandwich ELISA. Tidak ada nilai ambang batas untuk kadar endotoksin LPS. Hasil analisis kadar endotoksin lipopolisakarida dalam debu personal adalah sebagai berikut:

Tabel 2. Distribusi Kadar Endotoksin LPS Dalam Debu Personal Operator Penggilingan Padi di Desa Palur, Kecamatan Kebonsari, Kabupaten Madiun Tahun 2015

\begin{tabular}{cc}
\hline $\begin{array}{c}\text { Kadar Endotoksin LPS Dalam } \\
\text { Debu Personal }\end{array}$ & Jumlah $\left(\mathbf{E U} / \mathbf{m}^{3}\right)$ \\
\hline Minimum & 48 \\
\hline Maksimum & 66 \\
\hline Rerata \pm SD & $56,36 \pm 5.83$ \\
\hline
\end{tabular}

Tabel 2 menunjukan kadar endotoksin LPS paling rendah adalah $48 \mathrm{EU} / \mathrm{m}^{3}$, sedangkan kadar tertinggi sebesar $66 \mathrm{EU} / \mathrm{m}^{3}$. Rerata \pm SD

3) Hasil Pengukuran Jumlah Se Polymorphonuclear (PMN) Dalam Cairan Nasal Lavage Operator Penggilingan Padi

Sel PMN di periksa dalam sampel cairan nasal lavage yang diambil sebelum dan setelah bekerja (cross shift). Pemeriksaan dilakukan di laboratorium menggunakan metode hitung jenis leukosit. Selanjutnya hasil pemeriksaan kadar endotoksin LPS adalah $56,36 \pm 5.83$ $\mathrm{EU} / \mathrm{m}^{3}$.

laboratorium dianalisis secara statistik deskriptif yang meliputi rerata serta standar deviasi, nilai minimum dan maksimum, selain itu dilakukan juga uji beda (paired samples $t$ test) jumlah sel PMN sebelum dan setelah bekerja. Selengkap nya dapat dilihat pada tabel di bawah ini: 
Tabel 3. Distribusi dan Perbedaan Sebelum dan Setelah Bekerja (Cross Shift) Jumlah Sel PMN Dalam Cairan Nasal Lavage Operator Penggilingan Padi di Desa Palur, Kecamatan Kebonsari, Kabupaten Madiun Tahun 2015.

\begin{tabular}{cccc}
\hline Indikator & \multicolumn{3}{c}{ Jumlah Sel PMN (10 LP) } \\
Analisis & Sebelum Kerja & Setelah Kerja & $\Delta$ Sel PMN \\
\cline { 2 - 4 } & 4 & 14 & 2 \\
\hline Minimum & 14 & 24 & 20 \\
\hline Maksimum & $9.54 \pm 3.80$ & $20.27 \pm 3.19$ & $10.72 \pm 5.64$ \\
\hline Rerata \pm SD & & $\mathrm{p}=0.000^{* * *}$ & \\
\hline Paired t-test & & &
\end{tabular}

Keterangan: ${ }^{* *}=$ sangat signifikan

Tabel 3 menunjukan terjadi fagositosis. Rangsangan infeksi dan sitokin peningkatan jumlah sel PMN setelah proinflamasi menyebabkan PMN keluar dari bekerja pada semua responden. Jumlah sel aliran darah dan bermigrasi melalui jaringan PMN paling sedikit sebelum bekerja adalah 4 per 10 Lapangan Pandang (10LP) dan setelah bekerja 14 per 10LP sedangkan jumlah sel PMN terbanyak sebelum bekerja adalah 14 per 10LP dan yang setelah bekerja adalah 24 per 10LP. Rerata \pm SD jumlah sel PMN sebelum bekerja adalah $9.54 \pm 3.80$ per 10LP dan setelah bekerja adalah 20.27 \pm 3.19 per 10 LP. Terjadi peningkatan yang sangat signifikan jumlah sel PMN dalam cairan nasal lavage operator penggilingan padi setelah bekerja dengan nilai (Paired sampel t test; $\mathrm{p}=0.000)$.

\section{b. Pembahasan}

Sel PMN adalah bagian sel darah putih dari kelompok granulosit. PMN berperan pada inflamasi akut. Fungsi utama PMN adalah untuk sampai ke lokasi infeksi. Azurophilic dan butiran spesifik mengandung protein antimikroba yang memungkinkan PMN untuk membunuh mikroba (Baratawidjaja, 2010).

Hasil uji Paired $t$ Test menunjukan perbedaan yang sangat bermakna $(p=0.000)$ jumlah sel PMN sebelum dan setelah bekerja. Peningkatan jumlah sel PMN setelah bekerja ini mengindikasikan terjadi respon inflamasi pada roperator penggilingan padi setelah terpajan debu yang mengandung endotoksin lipopolisakarida. Endotoksin lipopolisakarida yang menempel pada dinding sel epitel IL-1 dan TNF- $\alpha$ yang kemudian menginduksi molekul adhesi (selectin $\mathrm{E}$ dan selectin $\mathrm{P}$, ICAM dan VICAM) yang berperan menarik 
Lamawuran, W. (2018). Peningkatan Polymorphonuclear (PMN) Dalam Cairan Nasal Lavage Operator Penggilingan Padi Yang Terpajan Endotoksin Lipopolisakarida (LPS). JURNAL INFO KESEHATAN, 16(1), 96-105. https://doi.org/10.31965/infokes.Vol16.Iss1.175

| 103

PMN untuk melepaskan molekul adhesi selectin, LFA-1 dan Mac-1 yang menyebabkan perlekatan yang lemah dengan kedua molekul tersebut pada endotel. Perlekatan PMN akan semakin kuat dengan bantuan leukotinin, PAF dan IL-8 sehingga PMN dapat keluar dari endotel ke jaringan yang diserang oleh endotoksin LPS dan selanjutnya PMN melakukan fagositosis. Fagositosis akan menghasilkan eksudat sehingga jaringan menjadi bengkak (tumor) dan jika PMN mati maka akan menyebabkan abses atau nanah (Baratawidjaja, 2013).

Polymorphonuclear (PMN) berperan dalam pertahanan tubuh terhadap infeksi bakteri dan respon inflamasi. PMN menjadi sel yang pertama hadir ketika terjadi infeksi. Sel PMN mempunyai sifat fagostik seperti makrofag yang menyerang pathogen dengan berbagai substansi beracun yang mengandung bahan pengoksidasi kuat, termasuk hydrogen peroksida, oksigen radikal bebas dan hipoklorit. Rasio sel darah putih dari PMN umumnya mencapai 50-60\%. Sum-sum tulang normal orang dewasa memproduksi kurang lebih 100 miliar PMN sehari dan meningkat menjadi sepuluh kali lipat jika terjadi inflamasi akut. Sel PMN yang rusak terlihat sebagai nanah (Janconova et al., 2011).
Fagosit merupakan factor penting yang berperan dalam respon inflamai akut karena kemampuannya untuk menelan dan merusak berbagai pathogen atau mikro bakterium secara efisien. Berbagai sel yang tergolong sebagai fagosit professional meliputi neutrophil, monosit, makrofag, eosinophil dan sel-sel dendrit. Pada kelompok sel ini PMN merupakan sel yang terbanyak dan merupakan sel yang paling awal berada pada daerah inflamasi dan merupakan komponen utama untuk respon imunitas natural selama infeksi akut (Quinn and Gauss, 2004).

\section{KESIMPULAN}

Terjadi peningkatan sangat signifikan jumlah Polymorphonuclear (PMN) dalam cairan nasal lavage operator penggilingan padi setelah terpajan debu yang mengandung endotoksin LPS.

\section{REFERENCES}

Antarudin, (2003). Pengaruh Debu Padi pada Faal Paru Pekerja Kilang Padi yang Merokok dan Tidak Merokok, Tesis Fakultas Kedokteran Universitas Sumatera Utara. http://www.repository.usu.ac.id/bitst ream (Sitasi 29 November 2014). 
Baratawidjaja KG., Rengganis I (2013).

Imunologi Dasar. Balai Penerbit

Fakultas Kedokteran Universitas Indonesia.

Baratawidjadja KG (2010). Imunologi Dasar.

Edisi 8. Balai Penerbit Fakultas

Kedokteran Universitas Indonesia. Jakarta

Becker S., Clapp W.A., Quai J., Fress K.L (1999). Compartmentalization of the inflammatory Respon to Inhaled Grain Dust. Am J Respir Crit Care Med, $160 \quad$ (4); 1309-1318. http://www.ncbi.nlm.nih.gov/pmc/ar $\underline{\text { ticels }}$ (sitasi 2 Desember 2014).

Clapp W D S., Becker J Q., Watt J L., Thorne P S., Frees K L., Zhang X., Koren H S., Lux C R., Schwartz D A (1994). Cytokine gene expression after inhalation of corn dust. American Journal of Respiratory and Critical Care Medicine (Impact Factor: 11.04). 10/1994; Source: PubMed. (sitasi 2 Desember 2014).

Djojodibroto R.D (2014). Respilogi. Penerbit Buku Kedokteran. Universitas Malaysia Sarawak.

Gezondheidsraad (2011). Grain Dust, Health Based Recommended Occupational Exposure Limit. http://www.gezondheidsraad.nl/sites (sitasi 25 November 2014).
Hermawan A.G. (2006). SIRS dan Spesis. Imunologi, Diagnosis, Penatalaksanaan. Surakarta: Sebelas Maret University Press.

Jancinova V., Perecko T., Nosal R., Mihalova D., Bauerova K., Drabikova K. (2011).Pharmacological regulation of neutrophil activity and apoptosis. Interdisc Toxicol. 2011; Vol. 4(1): 11-14. Published online in: http://www.intertox.sav.sk \& http://www.versita.com/science/med icine/it/ (disitasi pada 23 April 2015) Keman S (1997). Biomarkers of Chronic Non Spesific Airway Diseases - An Application of Molecular Epidemiology in Occupational Settings. Disertation. Netherlands: Maastricht University.

Keman S., Jetten, M., Douwes, J., Borm, P.J.A.(1998). Longitudinal Changes in Inflammatory Markers in Nasal Lavage of Cotton Workers: Relation to Endotoxin Exposure and Lung Function Changes. International Archive of Occupational and Environmental Health 71: 131-137.

Kennedy SM., Dimich-Ward H., Desjardin A., Kassam A., Vedal S., Chan-Yeung M (1994). Respiratory Health Among Retired Grain Elevator Workers.Am J Respir Crit Care Med 150: 59-65. 
Lamawuran, W. (2018). Peningkatan Polymorphonuclear (PMN) Dalam Cairan Nasal Lavage Operator Penggilingan Padi Yang Terpajan Endotoksin Lipopolisakarida (LPS). JURNAL INFO KESEHATAN, 16(1), 96-105. https://doi.org/10.31965/infokes.Vol16.Iss1.175

| 105

http://www.ajplung.physiology.org.

(sitasi 22 Februari 2015).

O’Grady N.P., Preas H.L., Pugin J. (2001)

Local Inflammatory Responses

Following Bronchial Enditoxin

Instillation in Humans. American

Journal of Respiratory and Critical

Care Medicine. 163: 1591-1598

Poole J.A. (2012). Farming-Associated Environmental Exposures and Effect on Atopic Disease. Ann Allergy Atshma Immunol. 109:93-98 (PMC free article) (PubMed). (sitasi tanggal 20 Februari 2015).

Quinn MT., Gauss KA. (2004). Structure and Regulation of the Neutrophile
Respiratory Burst Oxidase:

Comparation With Nonphagocyte

Oxidase. Journal of Leucocyte Biology. 76(4):900-914.

Schwartz DA., Landas SK., Lassise DL., Burmeistrer LF., Huninghake GW., Merchant JA (1992). Aiwway injury in swine confinement workers. Ann Intern Med. 116:360-5 (PubMed). (sitasi tanggal 25 Januari 2015).

Sirait, M. (2010). Hubungan Karakteristik Pekerja dengan Faal Paru di Kilang Padi Kecamatan Porsea tahun 2010. Skripsi. Fakultas Kesehatan Masyarakat Universitas Sumatera Utara, Medan.

Ready to submit your research? Choose INFOKES and benefit from:

- fast, convenient online submission

- $\quad$ thorough peer review by experienced researchers in your field

- rapid publication on acceptance

- $\quad$ support for research data

- Open Access which fosters wider collaboration and increased citations

- maximum visibility for your research

At Health Polytechnic of Kupang, research is always in progress.

Learn more http://jurnal.poltekkekupang.ac.id/index.php/infokes 